THE GRITICS DEBATE

General Editor: Michael Scott 
The Critics Debate

General Editor Michael Scott

PUBLISHED TITLES:

Sons and Lovers Geoffrey Harvey

Bleak House Jeremy Hawthorn

The Canterbury Tales Alcuin Blamires

Tess of the d'Urbervilles Terence Wright

Hamlet Michael Hattaway

The Waste Land/Ash Wednesday

Arnold P. Hinchliffe

Othello Peter Davison

Paradise Lost Margarita Stocker

King Lear Ann Thompson

The Tempest David Daniell

Coriolanus Bruce King

Blake: Songs of Innocence and Experience

David W. Lindsay

The Winter's Tale Bill Overton

Gulliver's Travels Brian Tippett

The Great Gatsby Stephen Matterson

To The Lighthouse Su Reid

Portrait of a Lady/Turn of the Screw

David Kirby

Hard Times Allen Samuels

Philip Larkin Stephen Regan

Measure for Measure T. F. Wharton

Wuthering Heights Peter Miles

The Metaphysical Poets Donald Mackenzie

Heart of Darkness Robert Burden

FURTHER TITLES ARE IN PREPARATION 


\title{
THE GREAT GATSBY
}

\author{
Stephen Matterson
}

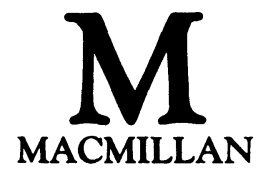


All rights reserved. No reproduction, copy or transmission of this publication may be made without written permission.

No paragraph of this publication may be reproduced, copied or transmitted save with written permission or in accordance with the provisions of the Copyright, Designs and Patents Act 1988, or under the terms of any licence permitting limited copying issued by the Copyright Licensing Agency, 90 Tottenham Court Road, London W1P 9HE.

Any person who does any unauthorised act in relation to this publication may be liable to criminal prosecution and civil claims for damages.

First published 1990 by MACMILLAN EDUCATION LTD

Houndmills, Basingstoke, Hampshire RG21 2XS and London

Companies and representatives throughout the world

ISBN 978-0-333-48307-7 ISBN 978-1-349-20768-8 (eBook) DOI 10.1007/978-1-349-20768-8

A catalogue record for this book is available from the British Library. 
For Jean, who gave so much 


\section{Contents}

General Editor's Preface

Introduction

ix

xi

Part One: Survey 1

The Great Gatsby and Myth 1

The American myth 2

The Non-American myth $\quad 6$

The Formalist Approach 9

The Great Gatsby as craft 11

Point of view $\quad 13$

$\begin{array}{ll}\text { Narrative } & 16\end{array}$

$\begin{array}{ll}\text { Symbolism } & 17\end{array}$

The Authorial Perspective 18

The place of The Great Gatsby in Fitzgerald's other works 18

'Winter Dreams' and "'The Sensible Thing", 20

'The Diamond as Big as the Ritz' and 'The Rich Boy' 22

'Absolution' 24

The Socio-historical Approach 25

The Great Gatsby and American themes 25

'The withering of the American dream' 27

The Discredited Dream $\quad 30$

East and West 33

Character $\quad 35$

Gatsby $\quad 37$

Nick Carraway $\quad 39$

Tom Buchanan $\quad 43$

Daisy Buchanan $\quad 44$

Jordan Baker $\quad 46$ 
viii THE GREAT GATSBY

$\begin{array}{ll}\text { Part Two: Appraisal } & 49\end{array}$

$\begin{array}{lr}\text { Introduction } & 49\end{array}$

The Clock and the Moon $\quad 51$

A Man's Book: The Great Gatsby and Women 57

$\begin{array}{lr}\text { The Great Gatsby and Social Class } & 59\end{array}$

The Great Gatsby and History $\quad 68$

$\begin{array}{ll}\text { References } & 73\end{array}$

$\begin{array}{ll}\text { Further Reading } & 77\end{array}$

$\begin{array}{ll}\text { Index } & 79\end{array}$ 


\section{General Editor's Preface}

OVER THE last few years the practice of literary criticism has become hotly debated. Methods developed earlier in the century and before have been attacked and the word 'crisis' has been drawn upon to describe the present condition of English Studies. That such a debate is taking place is a sign of the subject discipline's health. Some would hold that the situation necessitates a radical alternative approach which naturally implies a 'crisis situation'. Others would respond that to employ such terms is to precipitate or construct a false position. The debate continues but it is not the first. 'New Criticism' acquired its title because it attempted something fresh calling into question certain practices of the past. Yet the practices it attacked were not entirely lost or negated by the new critics. One factor becomes clear: English Studies is a pluralistic discipline.

What are students coming to advanced work in English for the first time to make of all this debate and controversy? They are in danger of being overwhelmed by the cross currents of critical approaches as they take up their study of literature. The purpose of this series is to help delineate various critical approaches to specific literary texts. Its authors are from a variety of critical schools and have approached their task in a flexible manner. Their aim is to help the reader come to terms with the variety of criticism and to introduce him or her to further reading on the subject and to a fuller evaluation of a particular text by illustrating the way it has been approached in a number of contexts. In the first part of the book a critical survey is given of some of the major ways the text has been appraised. This is done sometimes in a thematic manner, sometimes according to various 'schools' or 'approaches'. In the second part the authors provide their own appraisals of the 
text from their stated critical standpoint, allowing the reader the knowledge of their own particular approaches from which their views may in turn be evaluated. The series therein hopes to introduce and to elucidate criticism of authors and texts being studied and to encourage participation as the critics debate.

Michael Scott 


\section{Introduction}

In the Preface to his 1977 book on F. Scott Fitzgerald, the revision of a work first published in 1963, the critic Kenneth Eble took the opportunity to consider the strength of Fitzgerald's popularity and reputation during the preceding years. He noted various film and television productions based on Fitzgerald's novels, as well as the large number of critical books, scholarly articles, memoirs, and dissertations which had also appeared. Such a large amount of secondary work testified, Eble argued, to Fitzgerald's 'durability' as a writer. However, he went on, the cycle of Fitzgerald's popularity might well be coming to an end. He cited two major reasons for this: Americans might become less preoccupied than before with success, and fiction writers assuming popularity in the late 1970 s were departing from the realist tradition in which Fitzgerald's novels are rooted. Accordingly, decreasing preoccupation with success would make Fitzgerald's interest in the subject less relevant to a future generation. Along with the technical advances in literary ideas and concepts, Eble implied, the novels of Fitzgerald would seem anachronistic and unsophisticated.

However, since Eble wrote his Preface, there seems to have been no abatement of interest in Fitzgerald. A film of The Last Tycoon has been produced in Hollywood, with a screenplay by Harold Pinter. A BBC production of Tender is the Night was adapted by another leading British writer, Dennis Potter. There has been no lessening of critical and scholarly interest in Fitzgerald; and, strikingly, all of his novels are widely available in Penguin editions. The Collected Short Stories was published by Penguin in 1986, and Zelda Fitzgerald's novel Save Me the Waltz, has been made available, along with Andrew Turnbull's selection of Fitzgerald's letters. All of these facts testify, in spite of Eble's predictions, to that same 'durability' of Fitzgerald's work. 
The Great Gatsby has a life in different contexts, and to a large degree, the kind of novel that people discuss - that 'critics debate' - depends upon the perspectives from which they have chosen to view it. To the reader interested in Fitzgerald's life, there is ample material for a purely biographical approach. The novel is widely taught on courses in American Studies, with the assumption that it reveals something of the character of the American nation or culture at a given historical moment. A different approach might be to look at Fitzgerald's use of the Romantic tradition in literature, and at how his most famous novel relates to that tradition. Or, is it a novel best approached in terms of literary modernism - as a specific product of the mid-1920s? To some degree all of these approaches are valid, and all have been used by critics. In the contemporary critical climate, there are further issues that might usefully be raised in relation to this novel. Is Fitzgerald's treatment of women in the novel a major weakness? In what ways does it survive as a novel - how does it speak to us over sixty years after it was written, and what does it have to say? These are the kinds of questions that have assumed a critical validity during the past twenty years. It is also true that some of the developments in the novel genre, cited by Eble, have made possible other approaches to The Great Gatsby. In a counter-realist climate, the self-conscious narrator is a common figure; is it possible for us now to see Nick Carraway as such a narrator? For many readers and critics he has been an untrustworthy figure; thanks to the development of counter-realism, further emphasis could be placed on this aspect, with a fresh series of ideas about the novel. In short, the critical perspectives that can be adopted towards this novel are never necessarily fixed; they are always open to change, and it is a testimony to that continuing durability of Fitzgerald's work that we are still debating many of them.

For Part One of this book I have distinguished some of the most common approaches to the novel, and they are discussed in turn. Briefly, these are the mythic interpretations, the formalist emphasis, the place of The Great Gatsby in Fitzgerald's other writings, the socio-historical approach, and the questions raised about the novel's characters. While it is helpful to separate these approaches, it is important also to recognize that they do not necessarily exist separately from each other. For example, a 
particular approach to the character of Carraway influences other judgements about the novel. If one critic decides that he is an untrustworthy narrator, there will be inevitable implications for that critic's understanding of the novel's themes. Some of the possible approaches result in similar conclusions about the novel, while conflict and debate also arise. In Part Two of the book I examine some these issues in more detail, choosing several of the novel's themes that seem worthy of attention by a contemporary reader.

Throughout the book I have referred to the Penguin edition of The Great Gatsby. While the novel has been much reprinted in Penguin, the pagination has remained constant. The reader will note, however, that in referring to the character Meyer Wolfsheim, I have departed from the Penguin edition's spelling of his name as 'Wolfshiem'. This has been a standard practice among critics, referring back to the spelling in the novel's American editions. 